continued on its reaction with amines and with mercaptans. Investigations in the hydrogen embrittlement of certain steels continued, and also of the reaction between molten aluminium and water vapour. The total staff at December 31, 1962, was 51, including 25 graduates, and a list of publications is included.

\section{Employment of Graduates}

THE annual report of the University of Birmingham Appointments Board for the year ended December 31, 1962 , records a more selective attitude from employers (Pp. 6. Birmingham: The University, 1963). However, the anxiety of many firms not to become inbred is regarded as having prevented a squeeze on graduates with low honours or pass degrees, and competition is regarded as undoubtedly growing at this end of the academic scale. Of the 804 who obtained first degrees in 1962,762 registered, of whom 413 men and 33 women were in science, compared with 407 and 37 , respectively, in 1961. Of the graduates in science and technology, 6.3 per cent took teacher training and $2 \cdot 3$ per cent teaching posts in schools. Of 199 men who obtained first degrees in science in 196162,83 took up research work or further academic study at home and 6 overseas, 30 teacher training and 70 gained employment by December 1962; for 113 with higher degrees the corresponding figures are: 18, 22, 2 and 51 ; for 214 men with first degrees in technology, the corresponding figures are: $63,4,4$, and 127 ; and of 123 with higher degrees in technology, 7 took up research work or further academic study at home and 72 had gained employment by December 1962.

\section{The Carnegie Institution of Washington}

A Most attractive illustrated brochure issued by the Carnegie Institution of Washington describes concisely but clearly some of the achievements during the past sixty years of the Mount Wilson and Palomar Observatories, the Geophysical Laboratory, the Department of Terrestrial Magnetism, the Department of Plant Biology, the Department of Embryology, and of the Genetics Research Unit. The brochure shows very clearly the character of the Institution's work, which is now concentrated mainly in three broad fields: the form, contents and dynamies of the universe; the structure and evolution of the Earth; and the frontiers of biology (Pp. 20. Washington, D.C.: Carnegie Institution of Washington, 1963).

\section{The Transvaal Museum, Pretoria}

IN their annual report for 1962, the Board of Trustees of the Transvaal Museum, Pretoria, still trust that the recommendations of the two commissions of inquiry will be implemented ( $\mathrm{Pp}$. 38. Pretoria: Transvaal Museum, 1963). They deplore the present unsatisfactory circumstances both with regard to the Museum in general and the Cultural History Division in particular. Both the finance and space requirements are inadequate. The Museum was instrumental in promoting the Namib Desert Research Station Project. During the year, five large habitat-groups were completed, namely, sable, waterbuck, koedoe, mountain zebra and crocodile. Considerable additions have been made to the study collections, including several new and rare forms, especially among the insects. Some alleviation in the storage of large mammals and historical material was made possible by the renting of two storerooms outside the precincts of the Museum.

\section{Role of Microbiologists in Underdeveloped Countries}

IN a speech delivered last November to the American Society of Microbiology on the role of microbiologists in assistance programmes for undordovolopod nations, and now printed in the Journal of the Washington Academy of Sciences (April 1963), Dr. C. Lamanna makes three recommendations regarding the contribution of microbiologists, and illustrates their significance by describing briefly the results achieved by such an approach to the control of diarrhœal diseases in the Philippines. First, he recommends that the allocation of resources and the direction of the efforts of microbiologists should fit into a general scheme of balanced activities, aimed at raising living standards as a whole, including efforts to reduce barriers to change and to raise the economic resources of the community. Secondly, he stresses the need to reduce the cost of microbiological activities, both by simplification and the use of local substitutes for imported material where possible. Thirdly, the mierobiological research programmes in these countries should evolve by natural progression from efforts to meet practical needs. In this way the social value of microbiology would be demonstrated and the microbiologist himself would be required to accept his social responsibilities.

\section{Microbial Classification}

Arrangements are being made by the Canadian Committee on Culture Collections (in collaboration with the Numerical Taxonomy Sub-committee of the International Association of Microbiological Societies) to hold a Summer School Conference on Microbial Classification in late August or early September, 1964. Strong emphasis will be placed on the numerical taxonomy of bacteria, and most of the time will be given to discussion of focal topics, including theory and practice of microbial classification, data-processing methods, computers, and implications for culture collections and nomenclature. Further details can be obtained from Dr. C. Quadling, National Research Council of Canada, Sussex Drive, Ottawa 2, Ontario.

\section{Radioisotopes and lonizing Radiations in Entomology}

No. 9 in the bibliographical series published by the International Atomic Energy Agency, Vienna, is divided into two main sections dealing respectively with radioisotopes and ionizing radiations, and their uses in entomology; and thore is a short section concerned with nematodes in agriculture (Radioisotopes and Ionizing Radiations in Entomology. Pp. 414. Vienna: International Atomic Energy Agency; London: H.M.S.O., 1963. 168 Schillings; $48 s$.; 8 dollars; 32 N.F.; 28 D.M.). The references are arranged under authors' names in alphabetical order within each topic; the topics include ecology, physiology and biochemistry, insecticidal studies, practical applications in control, techniques, etc. Each reforenco is accompanied by an abstract of the contents. Data on special subjects, such as dispersal and flight range, radiation sterilization, metabolism of insecticides, have beon brought together in a series of tables in the appendix. An index to authors and a very detailed subject index are included. The period covered is $1950-60$ (very fow papers had been publishod before 1950) and the coverage must be almost complete. As a piece of bibliographical work it is well done (the compilation is by Mrs. M. Binggeli) and well produced. It is, of course, illogical to divide a science on the basis of a technique-but it may be none the less useful for that.

\section{The Department of Geology at the University of the Panjab}

A REPORT by Prof. N. R. Martin on the establishmont of the Department of Geology at the University of the Panjab, West Pakistan, 1952-62, under the expanded programme of technical assistance, which has rocontly been published by the United Nations Educational, Scientific and Technical Organization, summarizes the work of the Technical Assistance Mission in establishing this Departmont, to which contributions were made under the Colombo Plan, from the Leverhulmo Trust Fund and by the British Council, as well as by Unesco. The number of agoncios which participated in this project is one of the features of the whole project and it is also noteworthy 